\title{
Livelihood Dependence and Forest Reserve Management in Ijaiye Forest Reserve, Oyo State, Nigeria
}

\author{
Francis Chimezie Phillips ${ }^{1 *}$, Ebrima K. Ceesay ${ }^{2}$ \\ ${ }^{I}$ Pan African University, Institute of Life and Earth Sciences-University of Ibadan, Ibadan \\ ${ }^{2}$ University of the Gambia, Banjul, the Gambia
}

*Corresponding Author: Francis Chimezie Phillips, Pan African University, Institute of Life and Earth Sciences University of Ibadan, Ibadan

\begin{abstract}
Rural households living in the fringe villages of forest reserves depend primarily on agriculture and forest gatherings. High rate of dependency results from their efforts to secure and sustain livelihood. Consequently the forest reserve resource is faced with a decline in quality and quantity. However, due to excessive use, it will be difficult to expect that these resources will be available in the nearest future. In order to address this menace, this paper examines the effect of livelihood activities on sustainable management of Ijaiye Forest Reserve in Oyo state. It specifically evaluated land uselland cover changes in the reserve between 1984 and 2016, identified livelihoods tied to the resources in the Reserve, determined the factors affecting exploitation of forest resources in the Reserve, and assessed the sustainability of the forest resources management in the Reserve. Remote sensing techniques were used in evaluating land uselland cover change pattern in the study area over 32 years, employing LANDSAT satellite imageries of 1984 (TM), 2000 (ETM+) and 2016 (OLI). Supervised classification was done to unveil the land use/land cover characteristics. Crosssectional data were obtained from a sample of 321 household heads. In addition, In-depth Interviews and Key Informant Interviews were conducted for the Zonal Officer and other forest reserve officials. The data obtained were analysed using GIS tools, Descriptive statistics, Probit Regression model and Criteria and Indicator method of measuring sustainability. The results showed that there have been significant changes in land use which in every sense indicate resource degradation, over the study period. For example, fallow land, farmland and bare surfaces increased by more than 50\% while 'thick forest cover" decreased in comparable magnitude over the period. The result also showed that farming (89.1\%), non-timber resources gathering $(34.6 \%)$ and fuelwood collection (33.3\%) were the major livelihood activities of the people living in the area. Results showed that gender $(p>0.05)$, marital status $(p>0.01)$, primary occupation $(p>0.01)$, and frequency visit of the reserve $(p>0.01)$ increased the probability of exploiting forest resources while age $(p>0.10)$, educational status $(p>0.01)$, and distance of respondents' houses from the reserve $(p>0.10)$ decreased the probability of exploiting forest resources. High rate of vegetation loss and conversion, lack of management plan and inventory, paucity of funds for effective management, among others implied that the management of the Forest Reserve did not meet the criteria for sustainable forest reserve management. Coordinated actions involving for example, encouragement of the use of improved farming techniques, use efficient cooking appliances, enhancement of non-forest based activities in the area together with the development of a welltargeted and implementable forest reserve management plan are crucial to attaining sustainable forest management in the reserve. In this light, it is recommended that forest community members especially the young and active should be involved in the management of the forest reserve. Environmental education campaign should be undertaken involving the local communities. Funds, training and operational facilities should be made available for Forestry department and staff to foster effective management of the forest reserve.
\end{abstract}

Keywords: Sustainable forest reserve management, land use/land cover changes.

\section{INTRODUCTION}

Forests are land areas above 0.5 ha with a complex ecosystem consisting of a variety of plants, wild animals and microbes which interact with non-living abiotic factors FAO(2007). Forests are vital for rural livelihoods, biodiversity, climate change mitigation, energy supply, soil, water and wildlife protection Ajake and Anyadike (2012). They contribute significantly to the overall global energy supply particularly in rural areas; provide building materials and paper products; non-timber forest products including food, fodder and medicines, as well as cultural, spiritual and recreational values to 
millions of people Agbogidi and Eshegbeyi(2008).Despite the crucial importance of forests, each year some 13 million hectares of forest areas in the tropics are converted, mainly to agriculture FAO (2015). Over the years, there has been increased concern at both national and regional levels about the declining condition of forest resources Ajake and Anyadike (2012). Human pressure on forests and forest land has resulted into biodiversity loss, degrading forests, land and water, and emission of considerable amounts of carbon into the atmosphere Ajake(2008) with the greatest threats (most especially deforestation) occurring in developing countries within tropical ecosystems FAO(2007). Hence, the conservation of forest became an issue of increasing priority and urgency. Forest conservation is then needful, since it maintains all the essential functional components of the ecosystem in situ and constitutes the basis for the socio-economic livelihood of the rural people.

Central to the concept of conservation is sustainability. The concerns from sustained forest yield to sustainable forest management was first internationally initiated by the Brundtland Report on Sustainable Development in 1987 World Commission on Environment and Development (1987) and later taken as focus for global development during the Earth Summit in Rio de Janeiro in 1992, with the adoption of the Forest Principles (Robert 2003). Sustainable forest management is based on the broad consideration of environmental, social and cultural dimensions in a holistic manner when developing policies and plans for managing and conserving resources FAO (2015). The goal of sustainable forest management is to ensure that the significant benefits of forests are made available to the people who live in the forest or who rely on forests for their livelihoods, while at the same time conserving vital forest resources by increasing direct benefits to people and the environment; contributing to livelihoods, income generation and employment at the social level; and contributing to important services such as carbon sequestration and water, soil and biodiversity conservation at the environmental level (FAO, 2007; Dauet al., 2015).. Forest reserves are portions of state lands under reservation where commercial harvesting of wood products is controlled in order to capture elements of biodiversity Olujobi(2015). They are managed by the state government under the auspices of their forestry departments. Historically, reservation of land for forestry purpose was at its peak during the colonial era; this was done in order to manage, maintain forest resources and provide a supply of timber (FAO, 1999; Ayeni, 2013). This was followed by exploitation of forest resources to meet both export and increasing local demand as well as to earn foreign exchange Ayeni (2013).

As environmental degradation and its consequences come clearly into focus, humans are faced with the prospect that the renewable forest resources may be exhausted and that man stands the risk of destroying his environment if all the impacts of deforestation are allowed to go on unchecked FAO (2007). Greater attempts are now being made to rationalize the decision making process with res pect to the use of forest resources. There is need to ensure that the forest is managed in a sustainable manner if the resources of the forest will last long. In other words, the production of goods and services need to be balanced with the conservation of the resource base of the forest Dau et al.(2015). Furthermore, how best to manage forest resources by rural households so that they can make more income and even create more economic opportunities has become a growing concern for policy makers, interests groups and the public due to the following reasons: the increasing scarcity of virgin forest land; greater awareness and understanding of the social and economic implications of destructive forest practices especially at the rural level; and, a growing realization that the significant opportunities for economic development based on forestry activities should not be wasted Ezebilo(2004).

In Nigeria, there is evidence of increased degradation, conversion and depletion of forest ecosystems Abramovitz(1998). Over the last decades, significant portion of forest and forest reserve ecosystems have been lost (Eboh, 2000). The management of forest reserves in Nigeria is the responsibility of the state governments. How well or how far these state governments has ensured the sustainability of these forest reserves, in the light of the threats enunciated above, specifically in Ijaiye Forest Reserve is not well known. More so, the extent to which communities around this reserve depends on the forest resources remain an issue to be explored. Thus, this research seeks to examine 
contribution of the Ijaiye forest reserve to livelihood of communities around it and the effect of livelihood on forest reserve management in Ijaiye Forest Reserve. The broad objective of this study is to examine the effect of livelihood activities on sustainable management of Ijaiye Forest Reserve in Oyo state. The specific objectives are to; Evaluate the Land use / Land cover changes that have occurred between 1984 and 2016 in Ijaiye forest reserve; Identify livelihoods tied to Ijaiye forest reserve; Determine the factors that affect the exploitation of forest products in the forest reserve; Assess the sustainability of the forest resources management in Ijaiye forest reserve.

\section{METHODS}

The study is Ijaiye Forest Reserve, located $38 \mathrm{~km}$ north of Ibadan, Oyo State, Nigeria. The reserve is made up of two distinct types of vegetation, forest and savanna. The forest consists of evergreen plants and trees that grow to various heights whereas the savanna is characterized by grassland with scattered trees (Omagbemi, 2013).Ijaiye Forest Reserve was purposively selected for this study because of its large expanse, rich tree species diversity and its support for a wide range of economic activities associated with forest resources exploitation. The primary data for this study were obtained through In-Depth Interviews (IDI) and Household Interviews with a set of semi-structured questionnaires, Focus Group Discussion (FGD), and field observations.Secondary data used were Landsat Satellite Imageries of the study area for 1984, 2000, and 2016 which were obtained from the United State Geographical Survey (USGS) website. Others are textbooks, bulletins, periodicals, journals, annual reports, seminar papers, unpublished materials of relevance of the study.A multistage sampling procedure was used in selecting communities and respondents for this study. The first stage involved the random selection of ten (10) villages within $5 \mathrm{~km}$ radius of Ijaiye Forest Reserve which includes; Atan $(1 \mathrm{~km})$, Winsola $(1.5 \mathrm{~km})$, Batake $(2 \mathrm{~km})$, Idi Iya $(3 \mathrm{~km})$, Laduni $(3.1 \mathrm{~km})$, Safejo $(3.3 \mathrm{~km})$, Olubodi $(4 \mathrm{~km})$, Tola $(4.3 \mathrm{~km})$, Oke Lagan $(4.6 \mathrm{~km})$ and Akinde $(4.8 \mathrm{~km})$. This sampling was done by balloting. Names of the twenty (20) villages which were found around $5 \mathrm{~km}$ radius of the forest reserve were written in small sheets, folded and placed in a basket from which ten (10) villages were randomly selected without replacement. The second stage entailed a purposive selection of five villages from the ten (10) villages which include; Atan, Batake, Idi Iya, Laduni, and Tola. These five villages were selected based on their proximity to the reserve, predominance of exploitation of forest products in these villages, and availability of key informant. From these five villages, 321 households were randomly selected and interviewed.

For this study, Remote sensing and GIS techniques were employed to evaluate the land use/land cover changes that have occurred between 1984 and 2016 in the Ijaiye Forest Reserve. Three medium resolutions Landsat images of 1984(TM), 2000 (ETM+) and 2016 (OLI) were used to assess land use/land cover change patterns of the study area. The time intervals were selected based on availability of data. These images were obtained from the United States Geological Survey (USGS) website (http://glovis.usgs.gov/) as standard products, i.e. geometrically corrected. In order to avoid the impact of seasonal variation, all images were selected from the dry season in such a way that the cloud cover was less than $10 \%$. The images were also of the same level of spatial resolution of $30 \mathrm{~m}$ which makes it convenient for comparison of changes and patterns that occurred in the time under consideration

Table1. Lands at Data Characteristics

\begin{tabular}{|c|c|c|c|c|}
\hline Data & Source & Year & Category & Purpose \\
\hline Landsat 5 TM & USGS & 1984 & Secondary & Land cover and Land use characteristics \\
\hline Landsat 7 ETM+ & USGS & 2000 & Secondary & Land cover and Land use characteristics \\
\hline Landsat 8 OLI-TIRS & USGS & 2016 & Secondary & Land cover and Land use characteristics \\
\hline GPS Coordinates & Field work & 2017 & Primary & Reference data/ validation dataset \\
\hline High resolution image & Google Earth & 2017 & Secondary & Visual interpretation \\
\hline
\end{tabular}




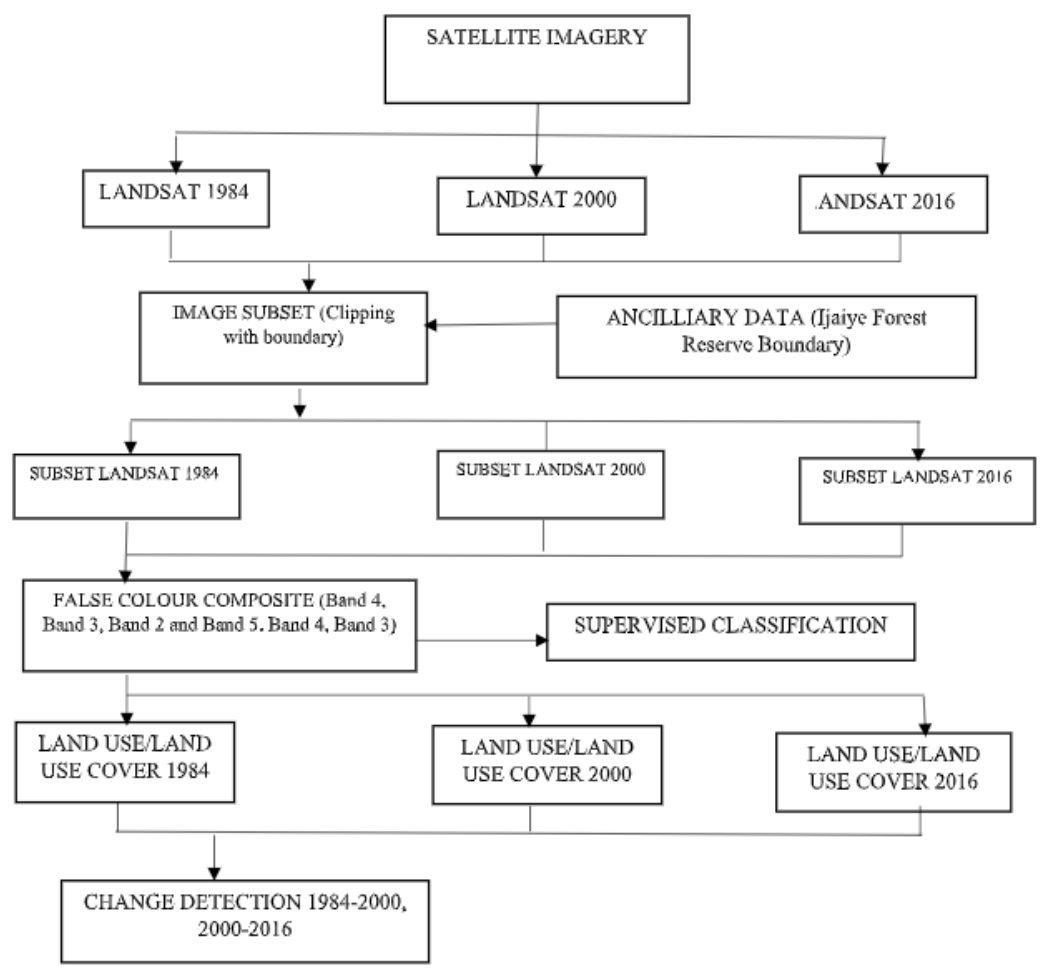

Figure1. Flowchart of the land use mapping methodology

Land cover maps were utilized to quantify land cover changes between 1984 and 2016 according to Melendez-Pastor et al. (2014). The statistics of land cover change was calculated as absolute percentage increments of the whole study area calculated by subtracting percentage areas among 2016 and 1984 and as relative percentage increments from 1984. The negative sign in the statistics indicated a loss in surface. Both approaches provided complementary information Adedeji et al. (2015). Software used in this study was ArcGIS 10.5, used to display, process and enhance images. ERDAS IMAGINE 10.0 was used for the development of land use/land cover classes and subsequently for the change detection analysis of the study area. Descriptive statistics which include frequencies, percentages, means and standard deviations were used to determine the contribution of the forest reserve to livelihood of the communities and present magnitude of land use/land cover changes in the forest reserve.

A number of factors affect forest products exploitation among communities close to forest reserves. In order to identify the factors that affect the exploitation of forest resources in Ijaiye forest reserve, regression analysis was carried out. The Probit model which is based on the cumulative normal probability function, can be written as follows can be specified as follows:

$F\left(X_{t}^{1} \beta\right)=\int_{-\infty}^{I_{t}} \frac{1}{\sqrt{2 \pi}} \exp \left(\mathrm{t}^{-t^{2} / 2}\right) d t$

Where:

$\mathrm{t}_{\mathrm{i}}=$ random variable with mean zero and unit variance.

The predicted probabilities are computed as; $\widehat{Y}_{t}=\widehat{P}_{t}=F\left(X_{t}^{1} \beta\right) \widehat{\beta}_{t}$.

SPSS Version 21 was used for analysis of data collected from the in-depth interview and questionnaire survey. Microsoft Excel 2013 was used for data entry of GPS location its conversion to degree and tract to the shape file. Microsoft Word 2013 was used basically for the presentation of the research.

Data were collected on the indicators of sustainability. The seven criteria defined by international processes are very similar, even though the indicators, which correspond to the identified criteria, should be closely linked to national conditions, needs and priorities. The following seven criteria and associated indicators developed or defined for the Nigerian context by Eboh (2000) was used to measure the current sustainability status of Ijaiye forest reserves in Oyo State; Ecosystem Diversity; Species Diversity; Genetic Diversity; Incidence of Disturbance and Stress; Ecosystem Resilience; Socio-Economic Integrity; Forest sector policy factors and management methods. 


\section{RESULT AND DISCUSSION}

\subsection{Socio-economic and Demographic Characteristics of Respondents}

Table 2 contains a summary the socioeconomic and demographic characteristics of the respondents. Close to seven-tenths $(68.2 \%)$ of the household heads were males while the remaining $31.8 \%$ were females. This implies that family headship in the study area is male dominated. This result may be connected with the fact that farming which is a male dominated activity is the dominant economic activity in the study area. more than two-fifths $(43.0 \%)$ of the respondents were between the ages of 31 and 45 years, and about a third (33.6\%) were between the ages of 46 and 60 years. The average age is 47.5 years $( \pm 13.9)$ which implies that most of the household heads are in their economically active years which may directly affect the extent and intensity of engaging in livelihood activities and in the exploitation of forest resources in and around the Forest Reserve. Almost three-quarters (74.8\%) of the households heads were married. These imply that a large proportion of the respondents around the reserve are settled with their families and can take advantage of household size for farm and forest exploitation activities. The result from the study showed that more than three-fifths $(62.9 \%)$ of the respondents had household size of between 6 and 10 with mean household size of 7 persons $( \pm 3.1)$. This suggests a good availability of family labour for farming and other activities which are carried out in and around the reserve. Results showed that more than half $(52.3 \%)$ of the respondents had no formal education; almost three-tenths $(29.9 \%$ ) had Primary Education and $9.7 \%$ as well as $6.2 \%$ had Secondary. This implies that the respondents had limited formal education. Result shows that more than half $(53.6 \%)$ of the households heads were non-indigene residing in and around the forest reserve while $46.4 \%$ are indigenes. Most (95\%) of the respondents have their houses within $5 \mathrm{~km}$ distance to the forest reserve with average distance from the forest reserve is $3.6 \mathrm{~km}( \pm 1.6)$. The length of visit have been for an average of 27 years $( \pm 9.0)$. This suggests that respondents have been visiting the forest reserve for a fairly long number of years. With regards to frequency of visit, more than threefifths $(61.4 \%)$ of the respondents said they visit the reserve every day.

Table2. Distribution of household heads by socio-economic and demographic characteristics

\begin{tabular}{|c|c|c|c|}
\hline Variables & Frequency & Percent & Average \\
\hline \multicolumn{4}{|l|}{ Gender } \\
\hline Male & 219 & 68.2 & \\
\hline Female & 102 & 31.8 & \\
\hline Total & 321 & 100.0 & \\
\hline \multicolumn{4}{|l|}{ Age (years) } \\
\hline$\leq 30$ & 32 & 10.0 & \\
\hline $31-45$ & 138 & 43.0 & \\
\hline $46-60$ & 108 & 33.6 & $47.5 \pm 13.9$ \\
\hline$>60$ & 43 & 13.4 & \\
\hline Total & 321 & 100.0 & \\
\hline \multicolumn{4}{|c|}{ Marital Status } \\
\hline Single & 6 & 1.9 & \\
\hline Married & 240 & 74.8 & \\
\hline Divorced & 38 & 11.8 & \\
\hline Widowed & 37 & 11.5 & \\
\hline Total & 321 & 100.0 & \\
\hline \multicolumn{4}{|c|}{ Household Size } \\
\hline $1-5$ & 88 & 27.4 & \\
\hline $6-10$ & 202 & 62.9 & \\
\hline $11-15$ & 27 & 8.4 & $7.1 \pm 3.1$ \\
\hline$>15$ & 4 & 1.2 & \\
\hline Total & 312 & 100.0 & \\
\hline \multicolumn{4}{|c|}{ Educational Status } \\
\hline None & 168 & 52.3 & \\
\hline Primary & 96 & 29.9 & \\
\hline Secondary & 31 & 9.7 & \\
\hline Tertiary & 6 & 1.9 & \\
\hline Arabic & 20 & 6.2 & \\
\hline Total & 321 & 100.0 & \\
\hline Origin & & & \\
\hline
\end{tabular}




\begin{tabular}{|c|c|c|c|}
\hline \multicolumn{2}{|c|}{} & \multicolumn{2}{|c|}{} \\
\hline Indigene & 149 & $\mathbf{5 3 . 6}$ & \\
Non-indigene & 172 & 100.0 & \\
Total & 321 & & $3.6 \pm 1.6$ \\
\hline Distance of reserve & & $\mathbf{9 5 . 0}$ & \\
from houses (km) & 305 & 5.0 & \\
\hline $1-5$ & 16 & 100.0 & \\
Total & 321 & & \\
\hline Years of visiting the & & $29.5 \pm 9.0$ \\
Reserve & 96 & $\mathbf{4 1 . 1}$ & \\
\hline$\leq 20$ & 132 & 22.7 & \\
$21-30$ & 73 & 6.2 & \\
$31-40$ & 20 & 100.0 & \\
$>40$ & 321 & & \\
Total & & $\mathbf{6 1 . 4}$ & \\
\hline Frequency of visiting & 197 & 24.6 & \\
the Forest Reserve & 79 & 10.6 & \\
\hline Everyday & 34 & 3.4 & \\
Once a week & 11 & 100.0 & \\
Once a month & 321 & & \\
Once a year & & & \\
Total & & & \\
\hline
\end{tabular}

\subsection{Land Use and Land Cover Dynamics and Changes in the Ijaiye Forest Reserve}

The study area covers 27,328 hectares (Jaiyesimiet al., 2012) and Land use/land cover changes were estimated from 1984 to 2016 . The classification of the multi-temporal satellite images into thick vegetation/forest, settlement, light vegetation/shrubs, farm/fallow land and bare land/marsh land was done for the three different time periods of 1984, 2000 and 2016. Land use/land cover (LULC) maps were also generated after classification for the periods (1984, 2000 and 2016) as shown in Figures 2, 3 and 4 respectively.

The comparison of the land cover maps of 1984, 2000 and 2016 showed the changes in the extents of forest, settlement, shrubs, farm/fallow land and bare ground over the period of study. In 1984, the largest single class of land use/land cover was thick vegetation/forests which covered 17825.41 hectares, representing $65 \%$ of the area of the forest reserve. This reduced significantly to $23 \%$ ( 6357.53 ha) in 2016 by 11467.87 hectares. Thus, this result confirms the growing and worrying spate of deforestation going on in many parts of the country. The settlement category which covered the smallest land area (877.65 ha) in 1984, representing $3 \%$ of the reserve, experienced an increase of 1,919.24 hectares between 1984 and 2000, but decreased by 1,267.41 hectares between 2000 and 2016. The reason is that some farm settlements are often temporary and can be overgrown by forests once abandoned. People may relocate to other areas as forest resources decline or in search of greener pastures. Overall, the settlement category experienced an average increase of 651.83 hectares throughout the study period. A noticeable increase occurred for the light vegetation/shrubs category, from $11 \%$ (3050.85 ha) in 1984 to $34 \%$ (9376.13 ha) in 2016, by which time it became the largest single cover class (Figure 2). This class had an increase of 6325.27 hectares over the study period which is the largest increase of all the classes of land cover. On one hand, the increase in the light vegetation/shrubs category can be attributed to a high gain from forest cover due to favourable climatic conditions. On the other hand, it depicts intense removal of thick forest cover which emanated from but not limited to unrestrained and uncontrolled logging with little or no re-planting of the harvested trees. In 1984, the farm/fallow land class was $11 \%$ (2883.12 ha) of the reserve. However, farm/fallow land area increased by 2741.16 hectares between 1984 and 2000 while it decreased by only 858.93 hectares between 2000 and 2016. Over the period of study, there was an increase of 1882.23 hectares in the farm/fallow land. The increase of the farmland is not far-fetched. These are the need for food security and livelihood sustenance of the teeming population living in and around the forest reserve. The household survey revealed that the majority of the household are farming households who are still involved in subsistent farming with bush fallowing method. A further notable change was the increase in the bare land/marsh land class from 2691.89 hectares in 1984 to 4116.29 hectares in 2000 and 5300.42 hectares in 2016. The bare land increased by 1424.40 hectares and 1184.13 hectares in the two periods respectively. Increase in bare ground/marsh land 
have also been caused by human activities that have persisted over time; clearing and opening up new areas.
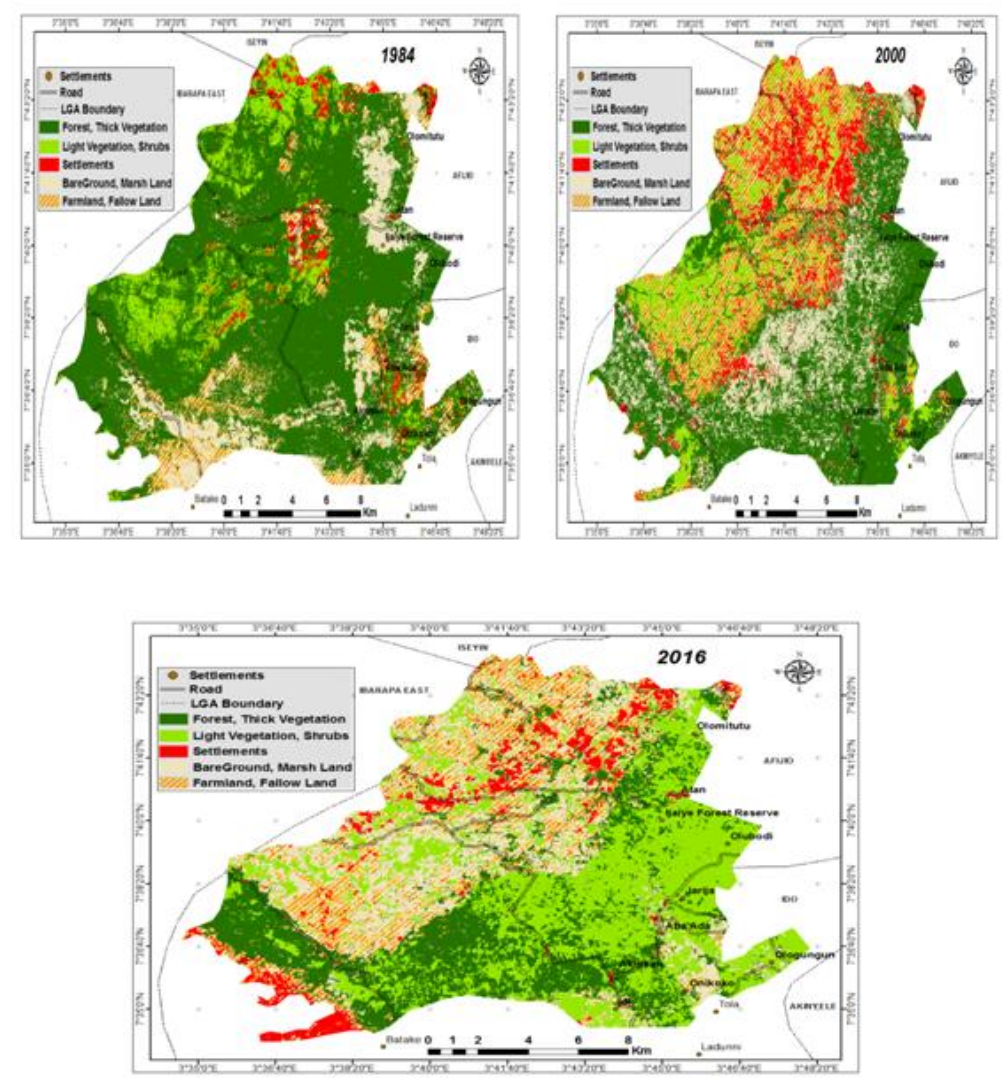

Figure2. Land use/land cover map of Ijaiye Forest Reserve in 1984, 2000, and 2016

\subsection{Livelihood Activities in and Around the Forest Reserves}

Table 2 shows the livelihood activities commonly engaged-in in the Forest Reserve. There were significant differences in the intensity of the practice of the livelihood activities in the forest reserve. Based on the frequency and percentage, nearly nine-tenths $(89.1 \%)$ of the respondents were engaged in farming, more than a third (34.6\%) were involved in NTFP gathering and a third of them (33.3\%) were involved in fuel wood collection. Only a little above one tenth (11\%) was involved in timber harvesting while close to a fifth (18\%) were into charcoal production.

Table3. Distribution of Livelihood Activities in the Study Area

\begin{tabular}{|c|c|c|c|c|}
\hline $\begin{array}{c}\text { Livelihood } \\
\text { activities }\end{array}$ & \multicolumn{2}{|c|}{ Frequency } & Yes & Percent \\
\hline Farming & Yes & No & 89.1 & 10.9 \\
NTFP gathering & 111 & 35 & 34.6 & 65.4 \\
Timber harvesting & 38 & 210 & 11.8 & 88.2 \\
Fuel wood collection & 107 & 283 & 33.3 & 66.7 \\
Charcoal production & 58 & 214 & 18.1 & 81.9 \\
Hunting & 77 & 263 & 24.0 & 80.1 \\
Others & 64 & 244 & 19.9 & 80.9 \\
\hline
\end{tabular}

\subsection{Factors Affecting the Exploitation of Forest Products in the Forest Reserve}

The factors that affect the exploitation of forest products in the forest reserve were determined using the probit regression model as described in the methodology. The results of the model are presented in Table 3 showing the estimated co-efficient, standard error, $t$-values and the marginal effects (the effect of a unit change in each explanatory variable on the probability of exploitation). The diagnostics reveal that the Chi-square value of 73.35 associated with the log likelihood ratio was significant $(\mathrm{p}<0.01)$ and pseudo $\mathrm{R}^{2}$ of 0.6298 suggesting strong explanatory power of the model which implies that the model has a good fit for the data. 
Of the twelve variables used in the model, seven were significant: Gender, Age, Marital status, Educational Status, Primary Occupation, Distance of reserve from home, and Frequency of visit to the reserve. This implies that decision to exploit forest products were significantly influenced by the aforementioned variables. The positive and negative signs attached to the coefficients shows the direction of the effect of each variables on the probability of exploiting the forest resources.

Coefficient for gender was found to be positive and significant at 5\%. This is means that being a male household head increase the probability of the exploitation of forest products in the forest reserve. The marginal effects estimates explain that probability exploitation of forest resources increases by $10.1 \%$. As expected, most men as household heads have the responsibilities to meet their family needs. They participate more in subsistence and cash income generating activities than women.In line with expectation, coefficient of age was negative and significant at $10 \%$ implying increase in the age of household heads reduces the probability of exploiting forest reserve resources. It is emphasized here that as people grow older the strength to carry out strenuous activities diminishes. This is the case of most aged people in the study area, where the very aged stay at home and allow the younger and more active individuals engage in demanding activities. Marital status, an important socioeconomic variable was significant at $1 \%$, having a positive sign. This implies that being married increases the likelihood that a household head will engage in the exploitation of forest products. The decision to exploit forest resources increase with having a family and by extension a large household size as previously reported in this study. As expected, the educational status had a significant (1\%) and negative effect on the exploitation of forest products. In other words, this means that with a higher level of education, the probability that a household head will engage in exploitation of forest resources decreases. This shows that as educational status increases, exploitation of forest reserve resources becomes less likely. It is assumed that the high level of education of respondents would lead to extraction of fewer forest products since education opens up alternative employment opportunities and diverts people from subsistence livelihoods activities such as the gathering of NTFPs from the forest reserve. The results also showed that primary occupation was significant at $1 \%$ and had a positive relationship with the probability of exploiting forest products. In other words, engaging in agricultural activities in the reserve increases the probability of exploiting forest products. Access to farmland within the forest reserve leads to uninterrupted exploitation of forest products. The main occupation represents the major economic activity engaged in by the household head for cash income and subsistence. Households who are engaged in other sectors of the economy such as trading and formal employment are less likely to be dependent on forest products compared to their counterparts in the farming enterprise Daneji and Suleiman (2011).

With respect to distance of the reserve from houses of respondents, the results revealed that the variable of distance of houses to reserve was negative and significant at $10 \%$. This suggests that the farther the respondents' houses from the reserve the less likely the household head will engage in the exploitation of the forest reserve. The closer the households are to the forest reserve, the easier and faster it is for them to access, harvest and utilize forest products. This indicates that rural communities closer to the forest reserve are expected to have limited livelihood options and may depend more on farming and extractive activities including but not limited to collection of forest products to meet their subsistence needs. In contrast, communities living farther away from the forest reserve may have a wide range of non-farm business opportunities and therefore may be less interested in the collection of forest resources. Perhaps, returns on labor and agricultural income are higher among communities that are far from the forest reserve, hence making them better off than their rural counterparts.

As regards frequency of visit to the reserve, its coefficient was positive and significant to the model at $1 \%$. This implies that visiting the forest reserve daily or every day significantly increase the probability that a household head will exploit forest products. However, the coefficients of annual income, type of activities carried out in the forest reserve, farming, timber harvesting and years of visiting the reserve were not significant.

Table4. Determinants of exploitation of forest products in the Forest Reserve

\begin{tabular}{|c|c|c|c|c|}
\hline $\begin{array}{c}\text { Exploitation of } \\
\text { Forest Products }\end{array}$ & Coefficient & Standard error & t-value & Marginal effects \\
\hline Constant & 1.9660 & 1.0137 & 1.94 & \\
\hline Gender & $0.8978^{* *}$ & 0.4108 & 2.19 & 0.1011 \\
\hline Age & $-0.0261^{*}$ & 0.0149 & -1.75 & -0.0403 \\
\hline
\end{tabular}




\begin{tabular}{|c|c|c|c|c|}
\hline Marital status & $0.6906^{* * *}$ & 0.2426 & 2.85 & 0.1807 \\
\hline Educational Status & $-0.1294 * * *$ & 0.1831 & -4.70 & -0.1304 \\
\hline $\begin{array}{c}\text { Primary } \\
\text { Occupation }\end{array}$ & $0.2940 * * *$ & 0.0991 & 2.97 & 0.1207 \\
\hline Annual Income & $1.16 \mathrm{e}-07$ & $4.94 \mathrm{e}-07$ & 0.23 & $1.81 \mathrm{e}-09$ \\
\hline $\begin{array}{c}\text { Distance of } \\
\text { Reserve from } \\
\text { Home }\end{array}$ & $-0.1860 *$ & 0.0965 & -1.93 & -0.0292 \\
\hline $\begin{array}{l}\text { Years of visiting } \\
\text { the Reserve }\end{array}$ & -0.0322 & 0.0217 & -1.48 & -0.0500 \\
\hline $\begin{array}{c}\text { Type of activities } \\
\text { carried out in the } \\
\text { Reserve }\end{array}$ & 0.8609 & 0.1098 & 1.18 & 0.0200 \\
\hline $\begin{array}{l}\text { Frequency of visit } \\
\text { to the Reserve }\end{array}$ & $0.6522 * * *$ & 0.1938 & 3.37 & 0.1020 \\
\hline Farming & 0.4887 & 0.4751 & 1.03 & 0.0460 \\
\hline Timber Harvesting & 0.4199 & 0.4607 & 0.91 & 0.0450 \\
\hline \multicolumn{5}{|c|}{$\begin{array}{l}\text { Number of observations }=321 \\
\text { LR chi2 }(12)=73.35 \\
\text { Prob }>\text { chi }^{2}=0.0000 \\
\text { Log likelihood }=-48.6480 \\
\text { Pseudo } R^{2}=0.6298\end{array}$} \\
\hline
\end{tabular}

*** Significant at $P<0.01$, ** Significant at $P<0.05$, * Significant at $P<0.1$

\subsection{Sustainability of the Management of the Forest Reserve}

Using the Criteria and Indicators (C \& I) defined for Nigerian context by Eboh (2000), this study evaluated the sustainability status of Ijaiye Forest Reserve, Oyo State.

\subsection{Proportion of Forest Reserve Currently Covered by Trees}

Of the total land area (27,328 ha) of Ijaiye forest reserve, only $20 \%$ was covered by trees by 2016. This implies that within 32 years i.e. study period, the forest reserve had lost about 12,820 hectares of trees. This gives an average loss of approximately $2.0 \%$ per annum. If this continues unchecked, the trees in Ijaiye Forest Reserve will last only for about 15 years before they are completely removed. It is clear that the management of Ijaiye Forest Reserve is not sustainable given the small amount of tree cover remaining, the rate of tree cover removal, inadequate staff strength and ill-involvement by the government. The finding of this study support the claims of Alamu and Agbeja (2011), and Eboh and Ujah (2003) that significant proportion of the forest and forest ecosystems have been lost to deforestation and degradation in the last two decades. Jaiyesimiet al. (2012) further stressed that large scale encroachments, allocation of forest land to non-forestry uses and ineffective implementation of forest policies and legislation have crippled sustainable management of forest reserves.

\subsection{Proportion of Prime and Minor Tree Species Remaining in Forest Reserve}

The forest reserve management of Ijaiye Forest Reserve confirmed that many of the original and minor tree species are no longer found in the reserve. The prime species remaining in the forest reserve are Gmelinaarborea, Tectonagrandis, Ceibapetandra, Albizziaspp, Triplochytonscleroxylon and Meliciaexelsa. However, only Gmelinaarborea, Tectonagrandis are presently widespread in the reserve. The other prime species are ageing and scattered. The minor tree species in the forest reserve are Cassia fistula, Cola nitida and Parkiabiglobosa. However, according to the forest officials, out of the remaining reserve area covered by tress, $40 \%$ are occupied by prime trees species while the remaining $60 \%$ are occupied by minor species. This implies that deforestation has depleted more of the prime tree species than the minor tree species because they command higher economic values than the minor tree species. Alamu and Agbeja (2011) stated that deforestation in South-West Nigeria is highly severe and this continues abated. They further highlighted some endangered tree species which include Melicia species, Triplochytonscleroxylon, Khaya species and Mansonia species. 


\subsection{Experience of Insect Attack, Disease Infestation and Fire Damage}

In Ijaiye forest reserve, there has never been any experience of insect attack on tree species. Also, there has never been any recorded case or experience of disease infestation in the reserve. This finding is similar to those of Eboh and Ujah (2003) who stated that there has never been any experience of insect attack on trees species in Mamu-River and Akwari-Ani forest reserves in Enugu State.

On the other hand, wildfire is a major problem in Ijaiye Forest Reserve. The forest guards and rangers assessed the incidence of wild fire to be considerable. The sources of this wildfire are illegal hunters, farmers and cattle herders who engage in bush burning to drive out games, clear land and rejuvenate fresh grass for their cattle. The problem of wildfire is often experienced annually and about $15 \%$ of the forest cover is said to have been lost as a result of wild fire. Similar findings were made by Emerhiet al. (2008) who observed that incidence of forest fires is common in the Forest Reserve.

\subsection{Forest Reserve Conversions and Volume of Forest Products Harvested}

Forest guards agreed that the incidence of access to farmland within the forest reserve is high. About $25 \%$ of the total land area has been converted to farmland and still increasing; about $12 \%$ has been lost to settlements and another 5\% has been lost to infrastructural development. The Zonal officer stated that forest conversion in the reserve is high especially to farming and this loss could be up to $5 \%$ on annual basis. Similar result was obtained by Eboh and Ujah (2003) and Ogunleyeet al. (2004) who found that anthropogenic activities in the forest reserve have resulted in large hectares of impoverished secondary forest, bare and degraded lands, grasslands and plantation of exotic species.

However, the Zonal officer stated that with respect to sustainable forest reserve management criterion, legal annual proportion of tree removal required for sustainability does not exist for Ijaiye Forest Reserve. This supports the earlier observation that there is no adequate management plan for the sustainability of the reserve. If the forests products are continuously harvested at the current rate of exploitation, it will be difficult to expect that these resources will be available in the nearest future.

\subsection{Enforcement of Laws/Regulations}

With respect to enforcement of laws, the management of the Forest Reserve were found to be unable to enforce properly the laws/rules/regulations guiding the utilization of forest reserve resources. When the forest officers were asked if they have been able to properly enforce the regulation guiding the utilization of forest reserve resources, they gave similar views that the enforcement is unsatisfactory. Similar findings were made by Eboh and Ujah (2003) and Adaohuruet al. (2012). Forest officials supported their views with a long list of bottlenecks and challenges. The obstacles noted as militating against the enforcement of rules/laws include; Shortage of personnel in all the cadres of Forestry, lack of Forest Labourers (Semi-Skilled Permanent Staff) usually responsible for nursery work, forestry boundary cleaning and patrol, lack of necessary logistics and operational facilities, obsolete Forestry Law, lack of Capacity Building for Forestry Staff, none usage of light arms by Forest Guards, inadequate information about the Forest Reserve, inadequate funding among others. As observed by Jaiyesimiet al. (2012) and Adaohuruet al. (2012), the work of the forest law enforcement agents in the Oyo State Reserves is very imperative to forest conservation, however, poaching, farming activities, and illegal felling constitute major threats.

\subsection{Availability of Management Plan and Up-to-date Inventory}

The Zonal officer claimed that there exists a Management Plan which was prepared when the forest reserve was established. However, the document could not be located. The Forest guards were in doubt whether the management plan, if available was ever implemented. Similar situation was observed by Eboh and Ujah (2003) in Enugu State Forest Reserves. There is also no up-to-date inventory of the forest reserve resources in the forest reserve. It is difficult to affirm the sustainability of a forest reserve without a management plan and an up-to-date inventory. This is the case with Ijaiye Forest Reserve. 


\subsection{Village/Community Participation and Conflict}

Just as confirmed by the household heads in the household survey, the Zonal forestry officer in charge of the forest reserve said that villages/communities are not involved in the management and decisionmaking concerning the forest reserve. Also, all the forest guards/rangers interviewed expressed similar views. Actually, they suggested that this may be one of the underlining factors breeding occasional conflicts in the reserve.

The Zonal officer confirmed that the Ijaiye forest reserve experienced the incidence of conflicts sometime in the past. He attributed this conflicts to the opposition of the local village/community to forest reserve laws/regulations and, most of the time, the inability of the government to pay royalties to these villages/communities. This situation is not favourable at all for sustainability of the forest reserve.

More recently, conflict sometimes occur between farmers and Fulani herdsmen. The Forest officials confirmed the occurrence of this conflict and had often times tried to settle such disagreement without any serious positive outcome. This rift is still ongoing. This situation likewise is not good for the sustainability of the reserve. Similarly, Barre (2012) found that forest communities in Ghana experience conflicts between indigenes and herders. Herders were usually accused of destroying crops and tree seedlings for farmers involved in Tuangya system farming.

\subsection{Reforestation Programme}

Apart from regeneration of trees and deployment of forest reserve rangers, no other serious practical step has been taken by the government over the years to ensure genetic conservation of commercial or endangered trees species. Studies which aim at identifying and developing trees species that will take less number of years to mature and give higher yield and quality such as is done in other parts of the world are absent.

All the same, the zonal forest officer claimed that they have artificially regenerated some portions (less than 10\%) while they have not been able to naturally regenerated any portion of the reserve due to the resistance from the local people who want to take care of their livelihood. The forest guards also confirmed awareness of reforestation programme in the reserve. This is evident in the existence and presence of exotic species of tress such as Gmelinaarborea and Tectonagrandisin the reserve. However, a lot still needs to be done with respect to the afforestation programme. This findings agree with Eboh and Ujah (2003) that there is evidence of afforestation programme in Enugu State Forest Reserves. This also corroborates the findings of Kaluet al. (2014) who affirmed the existence of afforestation and reforestation programmes in forest reserve areas in Imo State.

\subsection{Annual Forest Reserve Budget}

The zonal forestry officer rated the average annual forest sector share of the State's total annual budget as insufficiently insignificant. He added that the funds has been like that over the years and it is hampering the smooth running and management of the Ijaiye Forest Reserve and indeed other reserve in the State. This supports the position of Adedoyin (1995) who stated that forest reserve management suffers from lack of funds and inadequate personnel to perform their roles. Although, the revenue from the reserve is remitted into the government accounts, little or no funding is received for the forest reserve management. This problem was confirmed as the most important factor responsible for most of the challenges facing the forest reserve management. Forest officials highlighted other challenges facing the forest reserve to include: increased demand for agricultural land, lack of operational facilities, non-availability of forest management plan, unstable government policies, lack of political will and political influence.

From the discussion so far, it should be easy to deduce that Ijaiye forest reserves suffers from among other things, government's apathy to resource management and conservation. Considering the limited portion of the reserve covered by prime and minor trees, incessant fire incidence, alarming rate of forest conversion, weak enforcement of forest regulation; absence of adequate management plan, inadequate reforestation programme and paucity of forest reserve budget, one can conclude that the management of the Ijaiye forest reserve may not be sustainable. There is a need to pay more attention to sustaining the forest reserve given its overwhelming significance to the ecology and socio-economy of Oyo State. 


\section{CONCLUSION}

The socioeconomic characteristics of households around Ijaiye forest reserve in relation to their livelihood activities influence exploitation of forest resources. Gender, age, marital status, educational status, primary occupation, distance of reserve from home, and frequency of visit significantly affect exploitation of forest products. Livelihood activities in the reserve, which include farming, NTFP gathering, fuel wood collection and hunting, significantly help to sustain population in the study area. The intensity of livelihood activities and its impact on forest ecosystem were high. Significant land use/land cover changes which have occurred in the forest reserve over time is associated with increasing human activities in a bid to maintain livelihood. The management of Ijaiye forest reserve has not been able to meet the criteria for sustainable forest reserve management. Given the current management strategy and the continuous and high rate of forest loss and vegetation conversion, the sustainability of the forest reserve is in doubt. Very clearly, there is a need for improved policy and legislative framework on forests and forest reserves, if the government hopes to reverse the poor state of the reserve. Specific interventions are needed in local (community) participation in forest conservation and management; logistics, human resources and financial support for the management of the forest reserve. Support should specifically be made available for reforestation, tree regeneration efforts and effective protection of the reserve. All sustainability-threatening signals should also be taken serious if we must not lose all our forest reserve. Rural communities especially the young and active members should be involved in the management of the forests. Communities and villages roles and responsibilities in the management, conservation and use of the forests resource should be recognized and appreciated, since local communities are often highly dependent on this resource.

\section{REFERENCES}

[1] Abramovitz, J.N. (1998). Putting a value on Natures 'free' Services, Nature's Hidden Economy Worldwatch Institute, Vol. 11, No.1. Jan/Feb; 1998.

[2] Adaohuru A. R., J.C. Obiefuna, I.I. Ibeawuchi, and N.A. Okoli (2012). Evoking the knowledge of tree tenure in the humid tropics: a Review of dimensions in agro-plantation system in Nigeria. Journal of Agriculture and Social Research (JASR) Vol. 12, No. 1, 2012.

[3] Adedeji, O.H., Tope-Ajayi, O. O. and Abegunde, O. L. (2015). Assessing and Predicting Changes in the Status of Gambari Forest Reserve,Nigeria Using Remote Sensing and GIS Techniques. Journal of Geographic Information System, 7,301-318.

[4] Adedoyin, O.S. (1995). Nigeria Forest Resources Assessment. Report prepared for Worldwide Management, Evaluation and Coordinating Unit (FORMECU), and Federal Department of Forestry.

[5] Agbogidi, O. M. and Eshegbeyi, O. F. (2008). Forestry development for a safe environment. In: Onykwelu, J. C., Adekunle, V. A. J. and Oke, D. O. (eds). Research for development in forestry, forest products and natural resources management. Proceedings of the 1st national conference of the forests and forest products society of Nigerian (FFPN) held at the Federal University of Technology, Akure, Ondo State between 16th-18th April, 2008. Pp. 95-98

[6] Ajake A. O. and Anyandike R. N. C. (2012). Assessment of Forest Management Institutions and Their Initiatives in the Rainforest Communities of Cross River State, Nigeria Journal of Geography and Geology Vol. 4, No. 1; March 2012 http://www.ccsenet.org/jgg

[7] Ajake, A. O. (2008). Exploitation and management of forest resources in Cross River State, Nigeria. Unpublished Ph.D Thesis. Nsukka: University of Nigeria.

[8] Alamu and Agbeja (2011). Deforestation and endangered indigenous tree species in South-West Nigeria. International Journal of Biodiversity and Conservation Vol. 3(7), pp. 291-297. Available online http://www.academicjournals.org/ijbc.

[9] Angelsen A, Kaimowitz D (1999). Rethinking the Causes of Deforestation: Lessons from Economic Models. World Bank Res Obs. 14(1):73-98.

[10] Ayeni A. O. (2013). Forestry in Niigeria: A brief historical overview, phases of development and present challenges. africanremotesensing.org/page-1524987/1440697. Downloaded 19th of February, 2017.

[11] Barre R.Y. (2012). The Theoretical Milieu: Fulani herder-indigene conflicts in Tallensi-Nabdam, Ghana. Ghana Journal of Geography Vol.4, 2012 Pages $18-41$.

[12] Cavendish W. (2000). Empirical regularities in the poverty-environment relationship of rural households: evidence from Zimbabwe. World Dev. 28(11):1979-2003.

[13] Daneji MI, Suleiman MS (2011). Accessibility and utilization of agricultural information among farmers in Wudil Local Government Area, Kano State. Proceedings of the 36th Annual Conference of the Nigerian Society for Animal Production (NSAP) held at Abuja 13th - 16th March., pp 652-654. 
[14] Dau, J.H., Mati A. and Dawaki, S.A. (2015). Role of Forest Inventory in Sustainable Forest Management: A Review. International Journal of Forestry and Horticulture (IJFH) Volume 1, Issue 2, July - September 2015, PP 33-40 ISSN 2454-9487. www.arcjournals.org

[15] Dimobe K., A. Ouédraogob, S. Somab, D. Goetzec, S. Porembskic, A. Thiombiano (2015). Identification of driving factors of land degradation and deforestation in the Wildlife Reserve of Bontioli (Burkina Faso, West Africa). Global Ecology and Conservation 4 (2015) 559-571.

[16] Eboh E. C. and Ujah O. C. (2003). Measurement of Sustainability Indicators of Forests in Nigeria: A case study of forest reserves in Enugu State, Nigeria.

[17] Eboh, E, C (2000). "Land Tenure, Gender and the Sustainable Management of Forest and Farm-trees." Part 1 of Research Report Submitted to international foundation for science (IFS), Stockholm, Sweden, under Forest Grant No D/2608-D.

[18] Emerhi E. A., Ekeke B. A., and Oyebade B. A. (2008). Biodegrading effects of some rot fungi on Pinuscaribea wood. ISBN 1684-5315 http://www.ajol.info/index.php/ajb/article/view/58705/47031

[19] Ezebilo E. E. (2004). Threats to Sustainable forestry Development in Oyo State, Nigeria .published master's thesis in the Department of Southern Swedish Forest Research Centre Alnarp

[20] FAO (1999). Forest Resource Situation Assessment of Nigeria, April 1999 by Olufemi A. O. and Ameh C. E. http://fao.org/docrep//004/ab578e/AB578E11.html on 15th of February, 2017

[21] FAO (2007). State of the world's forests. Rome: FAO.

[22] FAO (2007). Sustainable Forest Management. http://www.fao.org/forestry. Downloaded17th of February, 2017

[23] FAO (2015). (www.fao.org/forestry/sfm/85084/en 2nd April, 2015). Downloaded on 17th of February, 2017.

[24] Iheke, O. R. (2010). Impact of Migrant Remittances on Efficiency and Welfare of Rural Smallholder Arable Crop Households in South Eastern Nigeria. Ph. D. Dissertation. Michael Okpara University of Agriculture, Umudike, Nigeria.

[25] IllukpitiyaPrabodh M.P. (2006). Agricultural Efficiency and Dependency on Forest Resources: An Economic Analysis of Rural Households and the Conservation of Natural Forests in Sri Lanka. A Dissertation submitted to the Graduate Division of the University of Hawai in partial fulfilment of the requirements for the degree of Doctor of Philosophy in Agricultural and Resource Economics.

[26] Inoni O.E. (2009). Effects of Forest Resources Exploitation on the Economic Well-being of Rural Households in Delta State, Nigeria. AgriculturaTropicaetSubtropica. Vol. 42(1) 2009.

[27] Jaiyesimi M. A., F.A., Adekanbi D.I., Akankuku A.I. and Obafunsho O. E. (2012). Forest Conservation Policy: The Role of State Forestry Department In Oyo State. Continental J. Agricultural Science 6 (3): 1 7, 2012

[28] Kabubo-Mariara J, Gachoki C. (2008). Forest Dependence and Household Welfare: Empirical Evidence from Kenya, CEEPA Discussion Paper No. 41

[29] Kalu, C.1, Edet, D.I and Chukwuenye, C.E. (2014). Assessment of Afforestation And Reforestation Efforts By Forestry Department, Ministry Of Environment, Imo State. jfewr @2014 - jfewr Publications.

[30] Melendez-Pastor, I., Hernández, E.I., Navarro-Pedreño, J. and Gómez, I. (2014). Socioeconomic Factors Influencing Land Cover Changes in Rural Areas: The Case of the Sierra de Albarracín (Spain). Applied Geography, 52, 34-45. http://dx.doi.org/10.1016/j.apgeog.2014.04.013.

[31] Muchapondwa E. (2003). The economics of community-based wildlife conservation in Zimbabwe (No. 130).

[32] Newton P., Miller D.C, Byenkya M.A.A, Agrawal A. (2016). Who are forest-dependent people? A taxonomy to aid livelihood and land use decision-making in forested regions. Land Use Policy 57:388395.

[33] Nwaru, J.C. (2004). Rural Credit Markets and Resource Use in Arable Crop Production in Imo State of Nigeria. Ph.D Thesis Michael Okpara University of Agriculture, Umudike.

[34] Ogunleye A.J., Adeola A.O., Ojo L.O., and A.M. Aduradola (2004). Impact of Farming Activities on Vegetation in Olokemeji Forest Reserve, Nigeria. Global Nest: the International Journal. Vol 6, No 2, pp 131-140, 200.

[35] Olujobi O. J. (2015). Evaluation of the contributions of Ikere Forest Reserve to sustainable livelihood of adjoining communities in Ekiti State. Journal of Research in Forestry, Wildlife and Environment Volume 7, No.2 September, 2015. ISBN: $2141-1778$ 
[36] Omagbemi N. T. (2013). Vegetation in Southwestern Nigeria. Geo-Information, The Ultimate Encyclopedia. http://geography-information.blogspot.com.ng/2013/09/vegetation.html.

[37] Robert A. Monserud (2003). Evaluating Forest Models in a Sustainable Forest Management Context; FBMIS Volume1; pp: 35-47; ISSN: 1740-5955; http://www.fbmis.info/A /3_1_MonserudR_1

[38] Shively G, and Pagiola S. (1999). Agricultural intensification, local labor markets, and deforestation in the Philippines. Environment and Development Economics 9(2):241-266.

[39] Suleiman M. S., V. O. Wasonga, J. S. Mbau, A. Suleiman and Y. A. Elhadi (2017). Non-timber forest products and their contribution to households' income around Falgore Game Reserve in Kano, Nigeria. Ecological Processes (2017) 6:23. DOI 10.1186/s13717-017-0090-8.

Citation: Francis Chimezie Phillips, Ebrima K. Ceesay, "Livelihood Dependence and Forest Reserve Management in Ijaiye Forest Reserve, Oyo State, Nigeria”, International Journal of Forestry and Horticulture, 6(2), pp. 26-39. DOI: http://dx.doi.org/10.20431/2454-9487.0602003

Copyright: (C) 2020 Authors, This is an open-access article distributed under the terms of the Creative Commons Attribution License, which permits unrestricted use, distribution, and reproduction in any medium, provided the original author and source are credited. 